\title{
Siyasal Toplumsallaşma Sürecinde İmam Hatip Liselerinin Rolü ${ }^{1}$
}

\author{
Şükrü Türköz²
}

\begin{abstract}
Özet
Toplumsallaşma, bireyin içinde yaşadığı toplumun kültürünü kazanma sürecidir. Siyasal toplumsallaşma ise genel toplumsallaşma sürecinin bir parçası olarak bireyin üyesi olduğu topluma ait siyasal kültürü içselleştirme süreci olarak tanımlanabilir. Siyasal toplumsallaşma çok erken yaşlarda başlayan ve bireyin hayatı boyunca devam eden bir süreçtir. Bu süreçte birey üzerinde aile, okul, akran grupları, siyasal olaylar, siyasal örgütler ve medya gibi aracıların belirli oranlarda etkisi bulunmaktadır. Bu araştırma bireyin siyasal toplumsallaşma sürecine etkisi bakımından "okulun", daha özelde ise İmam Hatip Liselerinin rolünü tespit etmeyi amaçlamaktadır. Bu kapsamda kartopu örneklem yöntemiyle tespit edilen 450 İHL mezununa anket uygulanmıştır. Anket verileri SPSS-24 istatistik programı yardımıyla analiz edilerek yorumlanmıştır. Araştırmada, siyasal toplumsallaşma sürecinde İHL'lerin mezunları üzerinde aile ve siyasal olaylar gibi aracılara göre sinırlı oranda bir etkisinin olduğu sonucuna ulaşılmıştır. Bununla birlikte nispeten eski ve yeni dönem mezunlar arasında siyasal kimlik bakımından belirgin farklılıklar tespit edilmiştir.
\end{abstract}

\section{Anahtar Kelimeler}

Siyasal Toplumsallaşma, İmam Hatip Liseleri, İHL Mezunları

1 Bu çalışma, Selçuk Üniversitesi Sosyal Bilimler Enstitüsü Sosyoloji Ana Bilim Dalında kabul edilen "Siyasal Toplumsallaşma Sürecinde İmam Hatip Liselerinin Rolü: Mezunlar Üzerine Bir Araştırma" başlıklı doktora tezinden üretilmiştir.

2 Niğde Ömer Halisdemir Üniversitesi, Niğde Sosyal Bilimler Meslek Yüksekokulu, sukruturkoz@ gmail.com, ORCID: 0000-0001-6185-3785. 


\title{
The Role of Imam Hatip High Schools in the Process of Political Socialization
}

\author{
Şükrü TÜRKÖZ
}

\begin{abstract}
Socialization is the process of gaining the culture of the society in which the person lives. Political socialization, as a part of the general socialization process, it can be defined as the process of internalizing the political culture of the society in which the person is a member. Political socialization is a process that starts at a very early age and continues throughout the life of the person. In this process, the agents such as family, school, peer groups, political events, political organizations and the media have certain effects on person. This research aims to determine the role of "school" in political socialization process, more specifically, it aims to identify the role of Imam Hatip High Schools. In this context, a questionnaire was applied to 450 IHL graduates determined by the "snowball sampling" method. The questionnaire data were interpreted with the help of SPSS-24 statistics program. In the study, it is concluded that IHL's have a limited impact on graduates in the process of political socialization, compared to agents such as family and political events. However, significant differences were found between old and new graduates in terms of political identity.
\end{abstract}

\section{Keywords}

Political Socialization, Imam Hatip High Schools, IHL Graduates

\section{دور الثانويات الأئمة والخطباء في عملية التنشئة الاجتماعية السياسية شوكرو تركوز \\ الملخص تركور}

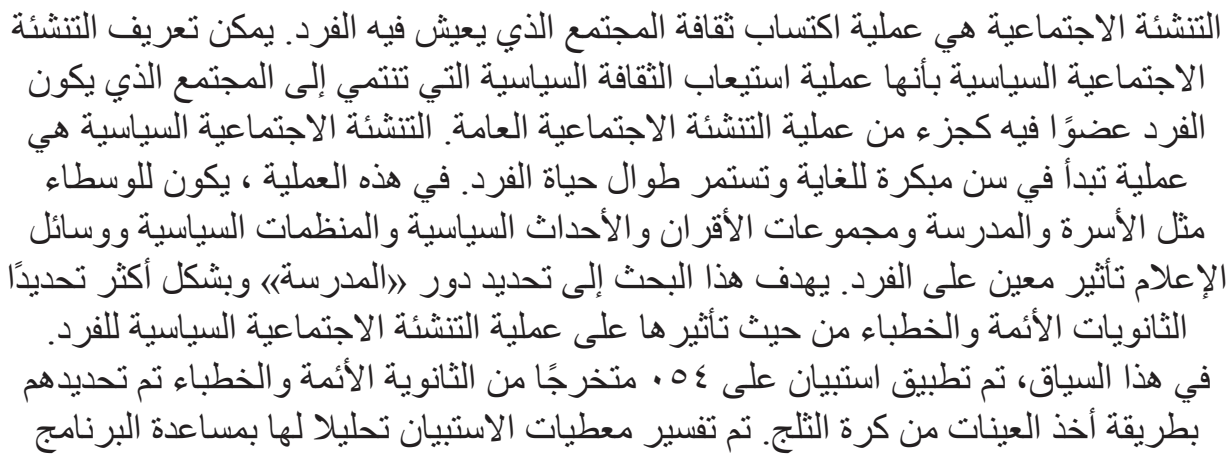




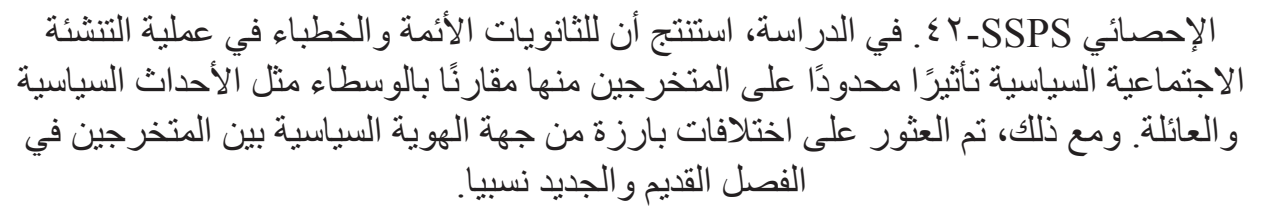

\section{الكلمات الرئيسية}

التنشئة الاجتماعية السياسية، الثانوية الأئمة و الخطباء، المتخرجون من الثانوية الأئمة الخطباء

\section{Giriş}

Toplumsallaşma, genel anlamda bireyin çocukluktan itibaren içinde yaşadığ 1 topluma uyum sağlama süreci olarak tanımlanabilir. Bu süreç, kişiye birçok alanda olduğu gibi içinde yaşadığı toplumun siyasal kültürü hakkında da bilgi sahibi olma imkânı tanımaktadır. Başka bir ifadeyle birey, genel toplumsallaşma sürecinin bir parçası olarak siyasal açıdan da toplumsallaşmaktadır. Bu bakımdan siyasal toplumsallaşma, bireyin hayatı boyunca devam eden bir süreç olarak kabul edilir ve bu süreçte birey üzerinde çeşitli faktörler etkili olabilmektedir. Alana ait literatüre göre, siyasal toplumsallaşma sürecinde birey üzerinde aile, okul, akran grupları, siyasal olaylar ve siyasal örgütler, kitle iletişim araçları ve diğer toplumsallaşma aracıları belirli oranlarda etkilidir. Bu araştırmanın sınırları dâhilinde, bireyin siyasal toplumsallaşma sürecine etkisi bakımından “eğitim sistemi ve okulun”, özelde ise İmam Hatip Liseleri (İHL)'nin rolüne odaklanılmıştır.

Türkiye'de İmam Hatip Liselerinin öğrencilerin siyasallaşma süreci üzerinde etkili olup olmadığı uzun yıllardır tartışılagelmiştir. Gökaçtı'ya (2005: 18) göre Türkiye'de İmam Hatipler Liseleriyle ilgili tartışmaların en önemli sebebi, "bu okullardan yetişen kitlenin sahip olduğu varsayılan farklı zihniyet dünyası dolayısıyla giderek toplumda daha etkin konuma gelmesinin, sonunda Cumhuriyet devrimlerinden ve kazanımlarından geriye dönüşe sebep olup olmayacağı" endişesidir. Söz konusu endişe daha çok laik çevrelerce dillendirilmektedir. Ancak Akşit'e (1993: 100) göre laik çevrelerde de İmam Hatip Liselerinin faaliyetleri hakkında görüş ayrılığı vardır. Bunlardan bazıları Cumhuriyet değerlerine bağlı "aydın din adamı" yetiştirilmesi amacıyla bu okulların açık kalması düşüncesini desteklemektedir. Bazıları ise İmam-Hatip Liselerini laik Cumhuriyet karşıtı ve radikal/militan İslamcı nesillerin yetiştirildiği okullar olarak gördüklerinden bu okulların yaygınlaşmasına kesinlikle karşıdır. Bununla birlikte "İmam-Hatip" karşıtlığı yalnızca laik çevrelere has bir durum değildir. İmam Hatip Liselerinin sayısal artışı İslami hassasiyete sahip kesimler tarafından hoş karşılansa da bazı cemaat ve tarikatlar İmam Hatip Liselerini, laik ulus devletin "dini alanın denetim altına alınmasında kullandığı bir araç” olarak görmüş ve bu okullara şiddetle karşı çıkmıştır (Akşit ve Coşkun, 2005: 394). İmam Hatip Liselerinin toplumsal tabanı olarak da adlandırılabilecek kesim ise dini eğitim ihtiyacının karşılanması noktasında yoğun bir destekle bu okullara sahip çıkmıştır. Diğer taraftan İHL camiasında bu okullardan 
yetişen nesillerin amaçlanan kalitede yetişmediği, özellikle son dönemde yaşanan nicelik artışına rağmen nitelik olarak bir gerileme olduğu yönündeki (Bkz. Karaman, 2014: 12; Kara, 2017: 287) eleştirel tartışmalar da devam etmektedir.

Görüldügü üzere İHL'ler ve mezunları çok sayıda eleştirel yaklaşımın muhatabı olmaktadır. Subaşı'na (2004: 129) göre söz konusu eleştiriler karşısında oluşan "kuşatılmışlık ve dışlanmışlık duygusu teolojik düzeyde arzu edilen başarının da bir türlü yakalanamaması ile birleşince" bu durum dolaylı olarak bir savunma psikolojisine dönüşmekte ve İHL mezunları sürekli olarak bu türden iddialar karşısında kendilerini geri plana çekerek içe kapanmakta, hatta bazen İHL mezunu olduklarını gizleyebilmektedir.

İHL'lerin öğrenci ve mezunları üzerindeki etkisinin siyasal boyutlarını analiz edebilmek ihtiyacına istinaden, bu çalışmanın temel amacı; İmam Hatip Liselerinin bireylerin siyasal kültürüne, siyasal tutum ve eğilimlerine ve neticede siyasal davranışlarına etki edip etmediği, eğer etki ediyorsa bu etkinin boyutlarını ve sınırlı1ıklarını tespit edebilmektir. Bu amaç doğrultusunda yanıtı aranan öncelikli sorular şunlardır;

i. İmam Hatip Liseleri'nin mezunlarının siyasal görüş, siyasal tutum ve siyasal davranışları üzerinde bir etkisi var mıdır?

ii. İHL mezunları siyasal kimlik bağlamında kendilerini nasıl tanımlamaktadır?

iii. İmam Hatip Liseleri, mezunları üzerinde ailelerden bütünüyle "farklı" ve yeni (veya özgün) bir siyasal kimlik oluşturmakta mıdır?

Çalışmanın omurgasını bu sorulara cevap bulmak oluşturmaktadır. Bu doğrultuda, İHL'den mezun olan bireylerin bizzat kendilerinden elde edilecek bulgular 1şı̆̆ında mezunların siyasal kültürü, siyasal davranışı, siyasal tutum ve eğilimleri hakkında fikir sahibi olmak hedeflenmektedir. Böylece yukarıda ana hatlarıyla çizilmeye çalışılan İmam Hatip Liseleri ve siyaset ilişkisi bağlamında zaman zaman gündeme gelen tartışmaların ideolojik bir çerçeveye hapsolmadan daha sağlıklı bir zeminde yapılmasına katkıda bulunmak amaçlanmaktadır.

\section{Siyasal Toplumsallaşma Kavramı}

En genel tanımıyla "toplumsallaşma, insanın toplumsal bir varlık haline gelerek toplumun üyesi olması ve kazandığı toplumsallığı hayatı boyunca sürdürmesi sürecidir. Bir toplumun üyesi haline gelmek, o toplumdaki toplumsal ilişkileri belirleyen normların, değerlerin, inançların benimsenmesi ya da içselleştirilmesini gerektirir" (Akın, 2011: 140). Bu benimseme sürecinde topluma/topluluğa ait kültürel değerler gelecek nesillere sistematik olarak aktarılır (Koştaş, 1987: 329). Çünkü "İnsan toplumları varlığını kültürel aktarma yoluyla devam ettirir. Toplumsallaşma ise bu kültürel aktarmayı sağlayan önemli bir unsurdur. Ortak hayatın kuralları ve normları, topluma yeni katılan bireylere toplumsallaşma yoluyla aktarılır" (Türkkahraman, 2000: 17). 
Bireyin siyasal açıdan toplumsallaşması olarak kısaca ifade edilebilecek siyasal toplumsallaşma ise aslında genel toplumsallaşma sürecinin bir türüdür. $\mathrm{Bu}$ yüzden siyasal öğrenme ve siyasal eğitim süreçlerini de içeren genel toplumsallaşma sürecinden bağımsız değildir. Siyasal toplumsallaşma ile diğer toplumsallaşma süreçleri arasında karşılıklı bir ilişki söz konusudur. İçinde yaşadığı topluma ait değer, tutum ve davranışları öğrenen bireyin genel toplumsallaşma süreci içerisinde yine aynı toplumda var olan siyasal fikirleri de öğrenmesi ve bu anlamda siyasal bir bilinç geliştirmesi kaçınılmazdır. Bu nedenle siyasal toplumsallaşma siyasetle ilgili bir öğrenme sürecidir. $\mathrm{Bu}$ süreçte kişi, siyasete katılma veya katılmama kararlarına etki eden faktörler ile kişilerarası ve kişinin devletle olan ilişkileri hakkında bir öğrenme sürecinden geçer (Türkkahraman, 2000: 23). Dolayısıyla süreç içinde birçok açıdan toplumsallaşan bireyin siyasal anlamda da bilince sahip olması beklenmektedir.

Genel toplumsallaşma sürecinin bir görünümü olan "siyasal toplumsallaşma", bireyin siyasal kimliğini, siyasal formasyonlarını (siyasal eğilim, ilke, davranış, beğeni vb.) kazanma ve siyasal sistemin bir unsuru olma sürecini kapsar (Beşirli, 2005: 252). Bireyin siyasi yönelimleri ve davranış biçimlerini edindiği (Easton, 1968: 125), içinde yaşadığı topluma ve mevcut siyasal sisteme sadakat bağlarının geliştiği bu süreç çok erken yaşlarda başlamakta ve yaşamı boyunca şekillenmektedir (Easton and Hess, 1962: 246). Siyasal bir sistemin hayatta kalması için toplumdaki bireyler olgunlaştıkça, sistemin onlardan beklenen bilgi, değer ve tutumları edinmeleri gerekir. İyi ya da kötü olsun eğer sistem devam edecekse, en geniş anlamda toplum üyelerini kendilerinden beklenen türden siyasi rollere göre eğitebilmelidir (Easton, 1957: 311). Hyman'a (1969: 10) göre de siyasal sistemlerin istikrarını koruyabilmesi için vatandaşlar siyasal davranışları çok erken yaşta öğrenmeli ve hayatları boyunca da bu davranışlarını devam ettirmelidir. Aksi halde toplumsal alanda düzensizlik ve hatta kargaşa meydana gelecektir.

Bütün bu hususları göz önünde bulundurarak kapsamlı bir tanım yapan Alkan'a (1979: 8) göre siyasal toplumsallaşma, "toplumsal-siyasal çevre ile birey arasında yaşam boyu süren dolaylı ve doğrudan etkileşim sonucunda, bireyin siyasal sistemle ilgili görüş, davranış ve değerlerinin gelişmesi” sürecidir. Bu bakımdan siyasal toplumsallaşma durağan olmayan, aksine devam eden bir süreç olarak insanların kendi toplumlarının siyasal sistemleriyle ilgili değerleri, normları ve motivasyonları kazanma sürecidir. İnsanlar bu yolla siyasal sistemin bir üyesi haline gelirler (Türkkahraman, 2000: 23). Süreç içerisinde birey hangi siyasi partiyi destekleyeceğine ya da seçimlerde oy verip vermemesi gerektiğine güncel siyasal gelişmeleri de değerlendirmek suretiyle karar verir. Bu anlamda siyasal toplumsallaşma süreci bireyin siyasal katılım kararına da doğrudan etki etmektedir.

\section{İmam Hatip Liseleri: Tarihsel Sürece Genel Bir Bakış}

Türkiye'de din eğitimi ve öğretimi denilince ilk akla gelen kurumlardan biri olarak İmam-Hatip Liselerinin geçmişi çok eskilere dayandırılmaktadır. Bu anlamda İslam dininin ilk eğitim-öğretim kurumu olan ve Hazreti Muhammed'in ashabına İslam 
dininin esaslarını öğrettiği ‘Suffe Mescidi’nin "İslam kültür ve medeniyetindeki eğitim kurumlarının şekillenmesinde bir model ve prototip" (Özensel ve Aydemir, 2016: 24) olduğu söylenebilir. Ancak literatürde İmam Hatip Liselerinin tarihsel anlamda daha çok bir Selçuklu-Osmanlı eğitim kurumu olan Medreselerin devamı olduğu görüşü ağırlıklı olarak kabul görmektedir (Ayhan, 2014; Aşlamacı, 2014; Öcal, 2017).

“Arapça bir kelime olan, 'ders okunan ve okutulan yer' anlamına gelen medreseler, İslam eğitim geleneğinde orta ve yükseköğretime denk gelen en önemli öğretim kurumları olmuştur" (Aşlamac1, 2014: 33). Vatandaşa din hizmetlerini sunacak din görevlilerini yetiştirme anlamında ise Osmanlı'nın son dönemlerine kadar İmam-Hatip yetiştiren medreseler haricinde 1913 tarihine kadar özel bir kurumdan bahsedilmemektedir (Özensel ve Aydemir, 2016: 24). Bu kapsamda Evkaf Nezareti tarafindan 6 Şubat 1912 tarihinde çıkarılan nizamname ile 'Kur'an ve sünnet çerçevesinde İslam'ın medeniyet kurup geliştiren bir din olduğunu, onun faziletlerini, güzelliklerini insanlık âlemine anlatabilecek kâmil din insanları yetiştirmek" amacıyla Medreset'ül Vaizin ${ }^{3}$ kurulmasına karar verilmiştir (Öcal, 2017: 118). Medreset'ül Vaizin, yaklaşı on aylık bir sürenin ardından, 1912 yılının son günlerinde (28 Aralık 1912'de) İstanbul Soğukçeşme'de Vani Efendi Medresesi binasında eğitim öğretim faaliyetlerine başlamıştır (Öcal, 2015: 66).

Bugünkü İmam Hatip Liselerinin ilk örneği sayılabilecek Medreset'ül Eimme ve'l Huteba ${ }^{4}$ (İmam ve Hatipler Medresesi) ise, Osmanlının son dönemlerinde adından da anlaşılacağı üzere imam ve hatip yetiştirmek amaciyla 1329 (1913) tarihinde yine Evkaf Nezareti'ne bağlı olarak açılmıştır. Tıpkı Medreset'ül Vaizin'de olduğu gibi, Medreset'ül Eimme ve'l Huteba'nın açılış gerekçesi de "dönemin imam ve hatiplerinde görülen kemiyet ve keyfiyet bakımından yetersizliklerdir" (Öcal, 2017: 121; Ergin, 1977: 163). Başka bir ifade ile milletin din hizmetlerine olan ihtiyacını yeterli seviyede karşılayabilecek, mesleki nitelikleri bakımından daha donanımlı imam ve hatipler yetiştirmek üzere bu kurum açılmıştır.

Cumhuriyet dönemine gelindiğinde, bilindiği üzere 3 Mart 1924 günü TBMM'de kabul edilen 430 sayılı Tevhid-i Tedrisat Kanunu, 6 Mart günü resmî gazetede yayınlanarak yürürlüğe konulmuştur. İmam-Hatip okullarının tarihi açısından önemli olan bu düzenleme ile ilgili kanunun 4. maddesi gereğince ülke çapında "imamet ve hitabet” gibi din hizmetlerini yürütmek üzere görevlendirilecek memurları yetiştirmek ve dini yükseköğrenimi tesis etmek amacıyla çalışmalara başlanmıştır (Öcal, 2017: 127). Bu kapsamda medreselerin yüksek kısımları İlahiyat Fakültelerine, orta kısımları ise İmam-Hatip mekteplerine dönüştürülmüştür (Alagöz, 2003: 573). İlk aşamada kanun

3 Kuruluş nizamnamesine göre Medreset’ül Vaizin'in öğretim süresi 4 yıldır ve müfredatında bugünkü İmam Hatip okullarının ders programlarının ilk örneği sayılabilecek bir metodla, dini ve seküler dersler birlikte planlanmıştır. Buradan mezun olanlar, askeri birliklerin imamlıkları ile vaizliklerine doğrudan atanabileceklerdi. Ayrıca, nitelikleri dikkate alınarak selatin camilerinin vaizliklerinde de görev yapabileceklerdi (Öcal, 2017: 118-20).

4 Medreset'ül Eimme ve'l Huteba, "Eimme ve Huteba" adlı imam ve hatipler yetiştiren kısmı ile "ezan ve ilahi” adlı müezzinler yetiştiren kısmı olmak üzere iki bölümden oluşuyordu. Ortaokul seviyesinde bir medrese olarak kurulmasına rağmen 1 yıllık kurslar şeklinde öğrenim vermiştir (Ergin, 1977: 163; Öcal, 2017: 121-2). 
gereğince ülke genelinde 29 İmam ve Hatip Mektebi açılmış ve bu okullara toplam 2268 öğrenci kayıt yaptırmıştır. Ancak bunlardan bir kısmı çeşitli nedenlerle okula devam edemediğinden eğitim-öğretim yılı sonunda öğrenci sayıs1, 1822'ye düşmüştür. İkinci öğretim yılı olan 1924-1925'te 5 okul kapatılmış ve 2 tane daha açılmıştır. 19251926 öğretim yılında ise 8'i kapatılıp 2'si yeni açılan ve böylelikle sayı olarak 20'ye gerileyen okullardaki öğrenci sayısı 1009'a gerilemiştir. 1926-1927 öğretim yılında ise okulların 18'i birden kapatılmış ve yenileri açılmamıştır. Geriye sadece İstanbul ve Kütahya İmam ve Hatip Mektepleri açık kalabilmiştir (Ergin, 1977: 2125). "Bu son 2 İmam ve Hatip Mektebi de 1929-1930 öğretim y1l sonunda resmen, 1931-1932 öğretim yılı sonunda ise fiilen kapatılmışlardır. Böylelikle toplam sayıları 33'ü bulan İmam ve Hatip Mektepleri tarihe intikal ettirilmişlerdir" (Öcal, 1999: 204).

Dini eğitim ve öğretim üzerindeki kısıtlamaların katı olarak uygulandığı yaklaşık 20 yıl boyunca "toplum dini hayat bakımından şiddetli baskı ve kontrol altında tutulmuş, Müslüman halkın dini hayatı koyu bir karanlığa ve cehalete gömülmeye başlamıştır" (Öcal, 2017: 151). Bu kapsamda özellikle din görevlisi yetiştirilmesindeki sıkıntılarla birlikte halkın din hizmetlerine olan ihtiyacı da giderek artmıştır. Reed'e (1955: 151) göre, 1924-1949 yılları arasında Türkiye'de devletin dini eğitimin yasaklanmasına dönük uyguladığı politikalar nedeniyle din hizmetlerini yürütecek görevliler (imam, müezzin, vaiz vb.) yetiştirilemediği için ülke genelinde 40 bine yakın köy, kasaba ve şehir merkezlerindeki birçok camide İmam-Hatip kalmamıştı. Bu dönemde Müslüman halk açısından büyük bir dini önder kıtlığı yaşanıyordu, zira 1924'te çıkan yasa ile medreselerin kapatılması sonucu ulema sayılabilecek dini önderlerin yenileri yetişmemişti. Mevcut olan az sayıdaki vasıflı ulemanın/imamların çoğu ya altmış yaşın üzerindeydi veya ölmüştü (Reed, 1955: 151).

Devletin dini eğitimle ilgili yasakçı politikalarının yol açtığı süreç halkın din görevlilerine olan talebinin giderek arttığı bir ortam hazırlarken, yaşanan sürecin devamında siyasal hayatta yeni bir gelişme olarak 1945 yılında çok partili sisteme geçilmiş ve 1946 'da ilk defa çok partili seçim yapılmıştır. Ancak seçimlerde "açık oygizli tasnif" sisteminin uygulanması sayesinde iktidar partisi olan CHP tekrar iktidara gelmiştir. Bununla birlikte iktidar partisi mensupları bir sonraki seçimlerde işlerinin zor olduğunu da görmüş ve gelecekte neler yapılması gerektiği ile ilgili konuları tartışmaya başlamışlardır. Dini alandaki yumuşama politikalarının tartışılması bağlamında 1947 yılında toplanan CHP Kurultayının bir dönüm noktası olduğu kabul edilebilir (Kara, 2019: 265). Bu anlamda Kurultayda söz alan birçok delege ${ }^{5}$ din eğitim ve öğretiminin yasaklanmasının ortaya çıkardığı olumsuz durumları ve bu husustaki vatandaş şikâyetlerini yoğun olarak dile getirmiştir (Öcal, 2015: 74).

Din öğretiminde boşluk yıllarının meydana getirdiği sıkıntılar ve halkın dini hizmetler noktasındaki taleplerinin bir sonucu olarak Kurultay sonrasında bazı kararlar alınmıştır. Bu kapsamda 10 Şubat 1948 tarihinde toplanan CHP meclis grubunda Başbakan Hasan

5 CHP'nin 7. Kurultayında “din eğitimi ve laiklik" hakkında yapılan konuşmaların tam metni için Bkz. (Ayhan, 2014: 107-125; Kara, 2019: 298-328). 
Saka'nın önerisi üzerine "ilkokullarda din derslerinin konulması ve imam ve hatip yetiştirmek amacıyla meslek okulları açılması" konularında inceleme yapmak ve rapor hazırlamak üzere 17 kişilik bir komisyon oluşturulmuş, bu komisyonun hazırladığı raporda imamlı ve hatiplik gibi din hizmetlerinin yerine getirilmesi noktasında elemanlar yetiştirilmesi tavsiye edilmiş̧ir (Öcal, 2017: 162). Anılan tavsiye kararı doğrultusunda, 20 Mayıs 1948 tarihinde toplanan Halk Partisi meclis grubu, sadece ortaokulu bitirenlerin ve askerlik ödevini yapmış olanların gidebileceği İmam ve Hatip yetiştirme kurslarının açılması ve organize edilmesi için Millı̂ Eğitim Bakanlığını yetkilendirmiştir (Jaschke, 1972: 77).

İmam-Hatip okullarının yeniden açılması ve sayılarında gözle görülür bir artışın gerçekleşmesi ise Demokrat Parti'nin (DP) iktidara geldiği 1950 yılından sonra meydana gelmiştir (Akşit ve Coşkun, 2005: 400). DP'nin iktidara gelmesinden kısa bir zaman geçtikten sonra vatandaşların talebi ve Celaleddin Ökten'in de gayretleri üzerine din görevlileri yetiştirmek amacıyla bir okul açılması hükümet tarafından kararlaştırılmıştır. Bu karar üzerine Milli Eğitim Bakanı Tevfik İleri tarafından bakanlık müsteşarının başkanlığında ve genel müdürlerden oluşan bir "Müdürler Komisyonu" oluşturulmuştur. Bu komisyon "İmam Hatip Okulu" adıyla 7 ilde 1951-1952 öğretim yllından itibaren eğitime başlamak üzere (İstanbul, Ankara, Adana, Kayseri, Konya, Isparta, Maraş) birer okul açılması kararını almış ve karar 17 Ekim 1951 tarihinde bakan Tevfik İleri tarafından onaylanmıştır (Öcal, 2015: 75).

İmam-Hatip okullarının niteliksel gelişimiyle ilgili en önemli gelişmelerden birisi 1973 yılında yaşanmıştır. 14 Haziran 1973 tarihinde yasalaşan 1739 sayılı Milli Eğitim Temel Kanunu'nun 32. maddesi gereğince "İmam Hatip Okulu” olan adı "İmam Hatip Lisesi” olarak değiştirilmiştir (Ünsür, 2005: 178). 1985 yllına gelindiğinde "1980'li yıllarda muhafazakâr kesimin yaşadığı toplumsal değişim ve dönüşümün” İHL'lere yansımasının çarpıcı örneği olarak gösterilebilecek gelişme ise, yeni ve farklı bir statüye sahip İmam-Hatip Lisesinin açılması olmuştur (Gökaçtı, 2005: 237). Bu tarihte ilk kez bir Anadolu İmam Hatip Lisesi İstanbul/Beykoz'da Almanca eğitim yapmak üzere açılmıştır (Gündüz, 1998: 554). 1990'lı yıllarda İmam Hatip Liseleri hakkında yürütülen tartışmalar bilimsel olmaktan ziyade siyasal boyutta yoğunlaşmış (Aşlamac1, 2014: 135), özellikle bazı medya organları kanalıyla bu okullara şüpheyle bakan laik çevrelerin endişeleri üzerinden, İHL'lerin laik cumhuriyet rejimine karşı bir tehdit oluşturduğu imajını kuvvetlendirmeye yönelik kamuoyu oluşturulmaya çalışılmıştır.

28 Şubat süreci ${ }^{6}$ sonrasında faaliyete geçirilen uygulamalar nedeniyle o tarihe kadar okul ve öğrenci sayılarında görülen muntazam artış birdenbire durmuş, sonrasında ise

628 Şubat 1997 tarihinde Başbakanlığını Necmettin Erbakan'ın yaptığı, Refah Partisi (RP) ve Doğru Yol Partisi (DYP) koalisyon iktidarı döneminde yapılan Milli Güvenlik Kurulu (MGK) toplantısında alınan kararlar nedeniyle İmam Hatip Okullarına devam eden öğrenciler ve onların velileri bazı sıkıntılar yaşamıştır. Postmodern darbe olarak da nitelendirilen "28 Şubat Süreci”, Türkiye'de siyasi, idari, hukuki ve toplumsal alanlarda bir dizi değişime neden olmuştur. Bu süreçte İslami hareketler "irtica tehdidi” olarak tanımlanmış ve ciddi şekilde baskı altına alınmıştır (Aşlamacı, 2014: 135). 
kayıtlı öğrenci sayısında keskin bir şekilde düşüş yaşanmıştır. Kamuoyunda "8 yıllık kesintisiz eğitim yasası"7 olarak bilinen 16 Ağustos 1997 tarih ve 4306 sayılı kanun ile İHL'lerin orta kısımları kapatılarak Kur'an Kurslarına kayıt yaptırabilmek için 8 yıllık ilköğretim mezunu olmak şartı getirilmiştir (Gündüz, 1998: 556). Yasanın ikinci maddesi gereğince 1997-1998 öğretim yılından itibaren İHL'lerin orta kısımlarına öğrenci alımı durdurulmuştur.

2002 yılında Adalet ve Kalkınma Partisi’nin (Ak Parti) iktidara gelmesiyle birlikte 28 Şubat sürecinin İHL'nin toplumsal tabanında yarattığı olumsuz etkilerin süreç içerisinde tedrici olarak ortadan kaldırıldığı görülmektedir. 2003 yılından günümüze değin gelen bu dönemde 28 Şubat süreciyle birlikte İmam Hatip Okullarında nicelik (özellikle okul, öğretmen ve öğrenci sayılarında) ve nitelik olarak yaşanan gerileme yerini pozitif bir ivmeye bırakmış, İHL'lerin toplumsal tabanının beklentileri (katsayı probleminin giderilmesi, okulların orta kısımlarının yeniden açılması, askeri ve polis okullarına girişteki yasakların kaldırılması vb.) siyasal iktidar tarafından yaklaşık 10 yıllık bir süreç içerisinde peyderpey karşılanmıştır.

Tablo 1.

2019 Yılı Toplam Sayılar

\begin{tabular}{|c|c|c|c|c|}
\hline \multirow{2}{*}{ Okul Türleri } & \multirow{2}{*}{$\begin{array}{l}\text { Okul/ } \\
\text { Kurum }\end{array}$} & \multicolumn{3}{|c|}{ Öğrenci Sayısı } \\
\hline & & Erkek & Kadın & Toplam \\
\hline $\begin{array}{l}\text { İmam Hatip Lisesi- Anadolu } \\
\text { İmam Hatip Lisesi }\end{array}$ & 1.610 & 221.296 & 273.080 & 494.376 \\
\hline $\begin{array}{l}\text { Anadolu İmam Hatip Lisesi } \\
\text { (Yabancı Uyruklular) }\end{array}$ & 13 & 2.494 & 1.132 & 3.626 \\
\hline Açıköğretim İmam Hatip Lisesi & 1 & 42.902 & 64.965 & 107.867 \\
\hline İHL Toplam & 1.624 & 266.692 & 339.177 & 605.869 \\
\hline İmam Hatip Ortaokulu & 2.847 & 314.326 & 339.534 & 653.860 \\
\hline $\begin{array}{l}\text { İmam Hatip Lisesi Bünyesinde } \\
\text { İmam Hatip Ortaokulu }\end{array}$ & 547 & 44.533 & 63.392 & 107.925 \\
\hline İmam Hatip Ortaokulu Toplam & 3.394 & 358.859 & 402.926 & 761.785 \\
\hline GENEL TOPLAM & 5.018 & 625.551 & 742.103 & 1.367 .654 \\
\hline
\end{tabular}

Kaynak: Millî Eğitim Bakanlı̆̆l, Strateji Geliştirme Başkanlı̆̆ (MEB-SBG), Milli Ĕ̈itim Ístatistikleri, 2019.

$7 \quad$ 16.08.1997 tarih ve 4306 sayılı İlköğretim ve Eğitim Kanunu, Millî Eğitim Temel Kanunu, Çıraklık ve Meslek Eğitimi Kanunu, Millı̂ Eğitim Bakanlığının Teşkilat ve Görevleri Hakkında Kanun ile 24.3.1988 Tarihli ve 3418 Sayılı Kanun'da Değişiklik Yapılması ve Bazı Kâğıt ve İşlemlerden Eğitime Katk1 Payı Alınması Hakkında Kanun (18.08.1997 gün ve 23084 sayılı Resmî Gazete). 
2019 y1lı itibariyle gelinen noktada genel bir değerlendirme yapılacak olursa, Tablo 1'de yer alan verilerden hareketle İmam Hatip Okulları açısından zikredilen "altın çă̆" tabirinin "nicelik" açısından isabetli bir tespit olduğu söylenebilir. Ancak sayısal olarak altın çağını yaşayan İmam Hatip Okullarının "nitelik” olarak beklenen verimin alınamadığ1 yönünde eleştiriler ${ }^{8}$ de mevcuttur (Bk. Karaman, 2014: 12; Kara, 2005: 36-37). Örgün ve açık öğretim programları dâhil toplamda 5018 okul ve 1.367.654 öğrencisiyle İmam Hatip Okulları bugün Türk Eğitim Sisteminde genel öğrenci kitlesinin yaklaşık \%12'sine ${ }^{9}$ tekabül etmekte, öğrencilerin aileleriyle birlikte değerlendirildiğinde çok daha geniş bir toplumsal tabanı temsil etmektedir.

\section{Yöntem}

Siyasal toplumsallaşma sürecinde İmam Hatip Liselerinin rolünü tespit etmeyi amaçlayan bu araştırmada bir nicel araştırma yöntemi olarak anket tekniği kullanılmıştır. Bu kapsamda saha araştırması aşamasında toplanan veriler SPPS 24 istatistik programı vasıtasıyla analiz edilmiştir. Ankette yer alan "Siyasal kimlik tercihi” ve "yaş gruplarına" ilişkin veriler frekans ve yüzde tabloları ile gösterilerek yorumlanmıştır. Ankette alt bir bölüm olarak bulunan ve içeriğinde siyasal toplumsallaşma aracılarının yer aldığı 20 ifadelik ölçeğe faktör analizi uygulanmış, oluşan faktörler t-Testi ve Tek yönlü varyans analizleriyle (ANOVA) yorumlanmıştır. Araştırmada elde edilen bulgulardan bütün İHL mezunlarını kapsayacak genel geçer çıkarımlar yapılmasından özellikle kaçınılmış ve sosyal gerçekliğin doğası gereği çok boyutlu görünümlerinin olabileceği göz ardı edilmemiştir. $\mathrm{Bu}$ bağlamda, İHL mezunlarının siyasal toplumsallaşma süreçlerinin de bireysel ve toplumsal açıdan farklı görünümler arz edebileceği genel kabulünden hareketle, araştırmada elde edilen bulgular bütüncül bir yaklaşımla farklı etkenler birlikte değerlendirilerek yorumlanmıştır.

\section{Evren ve Örneklem}

Araştırmanın evreni, 1951 yılında yeniden açılmalarından itibaren Türk Eğitim Sisteminde genel eğitim sisteminin bir parçası ve bir orta öğretim kurumu olarak yer alan İmam Hatip Liselerinden mezun olan tüm bireylerdir. Araştırmanın örneklemi ise Türkiye'nin farklı bölge ve yerleşim birimlerindeki İmam Hatip Liselerinden farklı dönemlerde mezun olmuş 18 ve 67 yaş aralığında, 218'i kadın ve 232'si erkek olmak üzere toplamda 450 kişiden oluşmaktadır. Örneklem, olasılıklı olmayan örneklem tekniklerinden "kartopu örneklem" tekniği ile tespit edilmiştir. Bireyler açısından çok özel sayılabilecek konularla ilgili yapılan bazı araştırmalarda deneklere ulaşmakta birtakım güçlükler yaşanabilmektedir. "Bu tür durumlarda, ilk araştırma grubu veya bireyler aracılığıyla yeni denekler bulmaya dayanan örneklem türüne

8 Konya İmam Hatip Okulu ilk mezunlarından (1958) olan Prof. Dr. Hayrettin Karaman mevcut İmam Hatip okullarının ilk zamanlardaki kaliteyi yakalayamadığını şu ifadelerle dile getirmektedir: “...Sayıları arttıkça keyfiyet itibariyle gerileyen mektepler” (Karaman, 2014: 12).

9 Ortaokul ve Lise Türkiye geneli toplam öğrenci sayısı 2019 itibariyle 11.276.669'dur (MEB-SBG, 2019, Strateji Geliştirme Başkanlığı, Örgün Eğitim İstatistikleri, http://sgb.meb.gov.tr/www/icerik goruntule.php?KNO=361(19.11.2019). 
kartopu örnekleme denir" (Erkuş, 2013: 124). Araştırma ilerledikçe, örneklem tıpkı bir kartopu gibi büyümekte ve analiz için yeterli sayıya ulaşılmaktadır (Yıldırım ve Şimşek, 2005: 111). "Kartopu örneklem tekniğinde deneklerin sosyal ağ bağlantıları kullanılarak yeni deneklere ulaşılması sağlanmaktadır" (Gürbüz ve Şahin, 2016: 135). Konusu gereği İHL-siyaset ilişkisine çağrışımda bulunan araştırma kapsamında veri toplamak amacıyla ulaşılan İHL mezunlarının önemli bir çoğunluğu araştırmaya katkıda bulunmak noktasında çekingen davranmıştır. Bu nedenle kartopu örneklem tekniğinin tabiatı gereği veri toplayabilmek amacıyla öncelikli olarak tespit edilen İHL mezunlarına ulaşılarak araştırmaya katılımları konusunda ikna edilmeleri sağlanmış, daha sonra görüşülen bu ilk katılımcıların İHL mezunu sosyal çevrelerine ise yine onların referansıyla ulaşılmıştır. Bu aşamada verilerin toplanması daha çok elektronik ortama aktarılan anket formunun "e-posta" veya "Whatsapp" gibi elektronik ortamlar kanalıyla yeni tespit edilen katılımcılara iletilmesi yoluyla elde edilmiştir.

\section{Hipotezler}

Araştırmanın kapsamı dâhilinde İHL mezunlarının siyasal toplumsallaşma süreçlerine etki eden faktörler bakımından mezunların sahip olabilecekleri siyasal tutum ve eğilimlerin sınanması amacıyla birtakım hipotezler üretilmiştir. Bu kapsamda araştırmada sınanan hipotezler aşağıdaki şekilde belirlenmiştir;

1. İmam Hatip Liseleri, mezunları üzerinde ailelerden bütünüyle "farklı ve/veya yeni” bir siyasal kimlik oluşturmamaktadır.

2. Siyasal kimlik bağlamında kendisini "Muhafazakâr, İslamcı, Milliyetçi veya Sağcı" olarak tanımlayan aileler çocuklarını genellikle İmam Hatip Liseleri’ne göndermektedir.

3. İHL mezunları büyük oranda ailelerinin siyasal tercihlerini benimsemektedirler.

4. İHL mezunları çoğunlukla "Sağ veya Muhafazakâr" siyasal kimliklere sahiptir.

5. Siyasal toplumsallaşma süreçleri açısından "eski" ve "yeni” kuşak mezunlar arasında belirgin farklılıklar vardır.

6. Siyasal toplumsallaşma sürecinde İHL'ler erkek mezunlar üzerinde daha çok etkilidir.

7. Siyasal toplumsallaşma sürecinde İHL'lerin etkisi mezunların "siyasal kimliğine" göre farklılık taşımaktadır. 


\section{Bulgular}

Araştırmaya katılan İHL mezunlarının kendilerini öncelikle nasıl tanımladıkları sorusuna verdikleri yanıtlar üzerinden oluşturulan tablo (Tablo 2) incelendiğinde, katılımcıların kendilerini en çok \%37,3 gibi yüksek bir oranla "Muhafazakâr" olarak tanımladıkları görülmektedir. Muhafazakârlıktan sonra en çok tercih edilen siyasal kimlikler ise \%24,5'le "Milliyetçilik" ve \%21,7 ile "İslamcılık" olmuştur. Kendisini "Demokrat" olarak tanımlayanların oranı ise \%6,6'dır. Alan araştırması sırasında seçeneklerde böyle bir tercih sunulmamasına rağmen katılımcıların \%5,2'si kendisini "Müslüman" olarak tanımlamayı tercih etmiştir. Diğer seçeneği içerisindeki \%4,7’lik kesimde ise sayica az da olsa kendisini "liberal, realist, vatansever, mutedil" gibi kimliklerle tanımlayanlar da mevcuttur. Katılımcıların toplamda \%83,5 gibi çok yüksek bir oranda kendisini tanımlarken Muhafazakâr, Milliyetçi veya İslamcı kimliklerinden birisini tercih ettiği görülmektedir. Bu durum "İHL mezunlarının çoğunlukla Sağ veya Muhafazakâr siyasal kimliklere sahiptir" şeklindeki hipotezi (hipotez-4) doğrulamaktadır. Katılımcılardan herhangi bir kişisel veri istenmemesine rağmen siyasal kimlikle ilgili soruyu mezunların \%5,8'i (26 kişi) cevapsız bırakmıştır.

Tablo 2.

Siyasal Kimlik Tercihi

\begin{tabular}{|l|c|c|c|c|c|c|c|c|c|}
\hline \multirow{2}{*}{ KIMLIKLER } & \multicolumn{3}{|c|}{ İHL Mezun } & \multicolumn{3}{c|}{ Baba } & \multicolumn{3}{c|}{ Anne } \\
\cline { 2 - 11 } & $\mathrm{N}$ & $\%$ & Geç. $\%$ & $\mathrm{~N}$ & $\%$ & $\begin{array}{c}\text { Geç. } \\
\%\end{array}$ & $\mathrm{~N}$ & $\%$ & $\begin{array}{c}\text { Geç. } \\
\%\end{array}$ \\
\hline Muhafazakâr & 158 & 35,1 & 37,3 & 186 & 41,3 & 45,6 & 202 & 44,9 & 49,3 \\
\hline Milliyetçi & 104 & 23,1 & 24,5 & 86 & 19,1 & 21,1 & 59 & 13,1 & 14,4 \\
\hline İslamc1 & 92 & 20,4 & 21,7 & 97 & 21,6 & 23,8 & 116 & 25,8 & 28,3 \\
\hline Müslüman & 22 & 4,9 & 5,2 & - & - & - & - & - & - \\
\hline Demokrat & 28 & 6,2 & 6,6 & 29 & 6,4 & 7,1 & 20 & 4,4 & 4,9 \\
\hline Diğer & 20 & 4,4 & 4,7 & 10 & 2,2 & 2,5 & 13 & 2,9 & 3,2 \\
\hline Toplam & 424 & 94,2 & 100,0 & 408 & 90,7 & 100,0 & 410 & 91,1 & 100,0 \\
\hline Cevaps1z & 26 & 5,8 & & 42 & 9,3 & & 40 & 8,9 & \\
\hline Toplam & 450 & 100,0 & & 450 & 100,0 & & 450 & 100,0 & \\
\hline
\end{tabular}

İHL mezunları ile ebeveynlerinin tercih ettiği siyasal kimliklere ait verilere göre katılımcıların siyasal kimliği ile anne ve babaların siyasal kimliğine ait oranlar büyük oranda benzeşmektedir (Bkz. Tablo 2). "Muhafazakârlık, Milliyetçilik ve İslamcılık" kimlikleri birbirine yakın oranlarda ve ilk üç sırada yer almaktadır. Ancak Milliyetçilik, ebeveynlerde en çok tercih edilen üçüncü siyasal kimlik iken, katılımcılar tarafından $\% 24,5$ ile en çok tercih edilen ikinci siyasal kimlik olmuştur. Bu verilerle örneklem dâhilindeki İHL mezunlarının özellikle siyasal kimlik tercihleri kapsamında İHL mezunu olmaktan daha çok ailelerinin siyasal kimliklerinden etkilenmiş oldukları tespit 
edilmiştir. $\mathrm{Bu}$ anlamda ailenin siyasal toplumsallaşma sürecinde çocuk üzerindeki önemli etkisinin İHL mezunları açısından da geçerli olduğu söylenebilir. Ayrıca, İHL mezunları arasında belirli oranda katılımcının ebeveynlerinden farklı olarak kendilerini siyasal bir kimlik olmamasına rağmen "Müslüman” olarak tanımladığı da görülmüştür.

Tablo 3.

Siyasal Kimlik ve Yaş Grupları (Çapraz Tablo)

\begin{tabular}{|l|c|c|c|}
\hline KİMLİKLER & X (39 ve üzeri) & Y (22-38 arası) & Z (21 yaş altı) \\
\hline Muhafazakâr & $\% 45,5$ & $\% 47,2$ & $\% 20,3$ \\
\hline Milliyetçi & $\% 14,2$ & $\% 14,8$ & $\% 43,2$ \\
\hline İslamcı & $\% 23,9$ & $\% 16,9$ & $\% 24,3$ \\
\hline Müslüman & $\% 11,2$ & $\% 4,9$ & - \\
\hline Demokrat & $\% 3,0$ & $\% 09,2$ & $\% 7,4$ \\
\hline Diğer & $\% 2,2$ & $\% 7,0$ & $\% 100$ \\
\hline Toplam & $\% 100$ & $\% 100$ & \\
\hline $\begin{array}{l}\left(\mathrm{X}^{2}=77,012, \mathrm{sd}=10,\right. \\
\mathrm{p}=0,000)\end{array}$ & & & \\
\hline
\end{tabular}

Siyasal kimlik ile yaş grupları arasında yapılan Ki-Kare analizinde bu iki sınıflayıcı değişken arasında anlamlı bir farklılaşma tespit edilmiştir (Ki-Kare=77,012, sd=10 $\mathrm{p}=0,000$ ). Buna göre İHL mezunlarından Z kuşağı içerisinde yer alan 21 yaş altı grupta bulunanlar kendilerini en fazla "Milliyetçi" $(\% 43,2)$ olarak tanımlarken, X $(\% 45,5)$ ve Y $(\% 47,2)$ kuşağında yer alan İHL mezunları kendilerini daha çok "Muhafazakâr” olarak tanımlamaktadırlar (Bkz. Tablo 3). Başka bir ifadeyle genç katılımcılarda Milliyetçilik oranı daha yüksekken yaş düzeyi arttıkça Muhafazakârlık kimliği daha çok tercih edilmektedir. Diğer taraftan kendisini “Müslüman” olarak tanımlayanların \%11,2'lik bir oran ile X kuşağında yer alırken Z kuşağı içerisinde kendisini Müslüman olarak tanımlayan hiçbir katılımcı yoktur. Kendisini "Demokrat" olarak tanımlayanların \% \%,2 ile en yüksek düzeyde temsil edildiği kuşak Y kuşağıdır. İslamcıların oranları ise Z $(\% 24,3)$ ve X \%23,9) kuşaklarında birbirine yakınken, Y kuşağında bu oran $(\% 16,9)$ daha düşüktür. 
Tablo 4.

IHL Mezunlarının Siyasal Toplumsallaşma Sürecine Etki Eden Unsurlara Uygulanan Faktör Analizinin Dönüşümlü Matrisi

\begin{tabular}{|c|c|c|c|c|c|}
\hline & \multirow[b]{2}{*}{ Ort. } & \multirow[b]{2}{*}{ St. Sp. } & \multicolumn{3}{|l|}{ Faktörler } \\
\hline & & & 1 & 2 & 3 \\
\hline \multicolumn{6}{|l|}{ İmam Hatip Lisesi } \\
\hline İHL'deki diğer öğretmenler & 1,95 & 1,248 &, 824 & & \\
\hline İHL mezunu arkadaş çevresi & 1,98 & 1,325 &, 805 & & \\
\hline İHL'deki meslek dersi öğretmenleri & 1,98 & 1,296 &, 796 & & \\
\hline İHL'deki okul ve sınıf arkadaşları & 2,00 & 1,304 &, 780 & & \\
\hline $\begin{array}{l}\text { İHL mezunlarının ağırlıkta olduğu siyasi parti } \\
\text { teşkilatları }\end{array}$ & 1,76 & 1,196 &, 775 & & \\
\hline İHL döneminde okunan ders harici yayınlar & 2,21 & 1,427 &, 749 & & \\
\hline İHL'deki ders müfredatı & 1,86 & 1,222 &, 760 & & \\
\hline $\begin{array}{l}\text { İHL ile ilgili STK'ların düzenlediği3 } \\
\text { etkinlikler }\end{array}$ & 1,59 & 1,073 &, 740 & & \\
\hline Genel olarak İHL mezunu olma & 2,33 & 1,489 &, 707 & & \\
\hline İHL mezunu akrabalar & 1,71 & 1,177 & ,696 & & \\
\hline İHL mezunu siyasetçiler & 2,17 & 1,445 &, 610 & & \\
\hline Dini grup sohbetleri & 1,95 & 1,361 &, 574 &, 451 & \\
\hline Dini liderler & 2,20 & 1,446 &, 563 & ,440 & \\
\hline \multicolumn{6}{|l|}{ Siyasal Olaylar ve Medya } \\
\hline Siyasal olaylar ve güncel siyasal gelişmeler & 2,90 & 1,618 & & ,853 & \\
\hline Devletin izlediği politikalar & 2,93 & 1,578 & & 841 & \\
\hline Basılı ve görsel medyada okunanlar/izlenenler & 2,61 & 1,510 & &, 739 & \\
\hline $\begin{array}{l}\text { Sosyal medyada (Facebook, Twitter, İnstagram } \\
\text { vs.) yapılan siyasi paylaşımlar }\end{array}$ & 2,15 & 1,385 & &, 576 & \\
\hline \multicolumn{6}{|l|}{ Aile } \\
\hline Baba & 2,43 & 1,454 & & &, 874 \\
\hline Anne & 2,14 & 1,351 & & & ,862 \\
\hline Kardeşler & 1,94 & 1,319 & & &, 726 \\
\hline \multicolumn{3}{|l|}{ Eigenvalue } & 7,36 & 3,41 & 2,75 \\
\hline \multicolumn{3}{|l|}{ Açıklanan Varyans $\quad$ Toplam: $\%$ 67,66 } & $\% 36,80$ & $\% 17,08$ & \%13,77 \\
\hline \multicolumn{3}{|l|}{ Cronbach's alpha } & 0,947 & 0,858 & 0,879 \\
\hline \multicolumn{3}{|l|}{ KMO Sampling adequacy } & \multicolumn{3}{|l|}{0,934} \\
\hline \multicolumn{3}{|l|}{ Barlett's test of sphericity } & \multicolumn{3}{|c|}{$\mathrm{X}^{2}=4713,963, \mathrm{sd}=190 \mathrm{p}=0,000$} \\
\hline
\end{tabular}

Çalışma kapsamında İHL mezunlarına siyasal görüşlerinin şekillenmesinde hangi aracıların ya da unsurların etkili olduğu sorulmuş ve bunların etki derecelerini düzenlenen ölçeğe göre "1. Hiç", "2.Çok az”, "3. Kısmen”, "4. Çok” ve "5. Çok fazla” 
şeklinde cevaplamaları istenmiştir. Ayrıca İHL mezunlarının siyasal toplumsallaşma sürecine etki eden kişileri ve unsurları içeren ifadelerin bulunduğu bölüme faktör analizi (KMO değeri: ,934) uygulanmıştır (Bkz. Tablo 4). Analiz sonucunda bahse konu etkenler ve unsurların 3 faktör altında toplandığı ve bu üç faktörün de \%67,66 gibi yüksek bir oranla toplam varyansın üçte ikisinden fazlasını açıkladığı tespit edilmiştir. İçeriğindeki İfadeler dolayısıyla ilk faktöre “İmam Hatip Lisesi” faktörü adı verilmiştir. Faktör altında toplanan ifadelerin ortalamaları oldukça düşük ve neredeyse hepsi "çok az" seviyesinde veya bu seviyeye yakındır. Dolayısıyla ilk faktör altındaki etkenlerin IHHL mezunlarının genellikle katılmadığı ifadelerden oluştuğu söylenebilir. Bu özelliklere sahip İHL faktörü, tek başına toplam varyansın \%36,80'ini açıklamaktadır ve eigendeğeri de 7,36'dır. Faktörü oluşturan ifadelerin güvenilirliği de oldukça yüksektir (Cronbach's alpha $=$,947).

Tablo 5 .

Cinsiyet ile "IHL” Faktörü Arasındaki İlişki (t-Testi Sonuçları)

\begin{tabular}{|l|l|l|l|l|l|}
\hline & N & Ortalama & $\begin{array}{l}\text { Std. } \\
\text { Sapma }\end{array}$ & F & Sig. \\
\hline Kadın & 218 & 48,5650 & 8,80780 & 2,989 &, 084 \\
\hline Erkek & 232 & 51,3484 & 10,25540 & & \\
\hline \multicolumn{7}{|l|}{} \\
\hline
\end{tabular}

\begin{tabular}{|c|c|c|c|c|c|c|c|}
\hline & \multicolumn{7}{|c|}{ Ortalamaların Eşitliği için t-testi } \\
\hline & \multirow[t]{2}{*}{$\mathrm{t}$} & \multirow[t]{2}{*}{ Sd. } & \multirow{2}{*}{$\begin{array}{c}\text { Sig. } \\
\text { (2-tailed) }\end{array}$} & \multirow{2}{*}{$\begin{array}{c}\text { Ortalama } \\
\text { Fark1 }\end{array}$} & \multirow{2}{*}{$\begin{array}{c}\text { Standart } \\
\text { Hata } \\
\text { Fark1 }\end{array}$} & \multicolumn{2}{|c|}{$\begin{array}{l}\text { Farkın \%95 } \\
\text { Güven Aralığı }\end{array}$} \\
\hline & & & & & & Alt & Üst \\
\hline $\begin{array}{l}\text { Varyanslar eşit } \\
\text { sayıldığında }\end{array}$ & $-3,080$ & 448 & ,002 & $-2,78335$ & ,90380 & $-4,559$ & $-1,007$ \\
\hline $\begin{array}{l}\text { Varyanslar eşit } \\
\text { sayılmadığında }\end{array}$ & $-3,094$ & 444,460 & ,002 & $-2,78335$ & ,89955 & $-4,551$ & $-1,015$ \\
\hline
\end{tabular}

Cinsiyet bağımsız değişkeni ile İHL faktörü arasında anlamlı bir farklılık ilişkisi tespit edilmiştir ( $\mathrm{t}=-3,080, \mathrm{sd}=448, \mathrm{p}=, 002)$ (Bkz. Tablo 5). Bu faktör altında toplanan ifadeler bakımından erkeklerin ortalaması kadınlardan daha yüksektir. Dolayısıyla İHL'lerin siyasal toplumsallaşma sürecinde erkek mezunlar üzerinde kadınlara göre daha etkili olduğu ve araştırmanın bu yöndeki hipotezinin (hipotez-6) doğrulandığı söylenebilir. 
Tablo 6 .

Yaş Grupları ile “iHHL” Faktörü Arasındaki İlişki (Varyans Analizi)

\begin{tabular}{|l|l|l|l|l|l|}
\hline & $\begin{array}{l}\text { Kareler } \\
\text { Toplamı }\end{array}$ & Sd. & $\begin{array}{l}\text { Ortalamanın } \\
\text { Karesi }\end{array}$ & F & Sig. \\
\hline $\begin{array}{l}\text { Gruplar } \\
\text { Arasinda }\end{array}$ & 5211,991 & 2 & 2605,995 & 31,665 &, 000 \\
\hline $\begin{array}{l}\text { Gruplar } \\
\text { Dahilinde }\end{array}$ & 36788,009 & 447 & 82,300 & & \\
\hline Toplam & 42000,000 & 449 & & & \\
\hline
\end{tabular}

\begin{tabular}{|l|c|l|l|l|}
\hline & N & Ort. & St.Sp. & Çoklu Karşılaştırma (Tamhane Testi) \\
\hline 21 ve altı (Z) & 168 & 46,8270 & 7,33016 & 39 ve üstü $(X)^{*}$ \\
\hline 22-38 arası (Y) & 147 & 49,0296 & 9,33245 & 39 ve üstü $(X)^{*}$ \\
\hline 39 ve üstü (X) & 135 & 55,0053 & 10,61506 & 21 ve altı $(Z)^{*} 22-38$ arası $(Y)^{*}$ \\
\hline Toplam & 450 & 50,0000 & 9,67167 & \\
\hline
\end{tabular}

Not: (*) 0,05 düzeyinde anlamlı olduğunu göstermektedir.

“İmam Hatip Lisesi” faktörü kapsamında benzer bir farklılık ilişkisi de kuşaklar ${ }^{10}$ (yaş grupları) arasında görülmektedir $(\mathrm{F}=31,665, \mathrm{p}=, 000)$ (Bkz. Tablo 6). Yapılan varyans analizine göre, $\mathrm{X}$ kuşağına mensup katılımcılar, İHL faktörü altındaki ifadeler açısından $Y$ ve $Z$ kuşaklarına mensup katılımcılardan anlamlı bir şekilde farklılaşmaktadır. Y ve $Z$ kuşağı arasında anlamlı bir farklılık yokken, özellikle Z kuşağının ortalaması, X kuşağından belirgin şekilde düşüktür. Dolayısıyla, İHL'lerin genç mezunların siyasal toplumsallaşma süreçlerinde nispeten daha az etkili olduğu anlaşılmaktadır. İHL'lerin siyasal görüşlerine en yüksek oranda etki ettiği kuşak ise X kuşağıdır. Bu veriler, "siyasal toplumsallaşma süreçleri açısından eski ve yeni kuşak İHL mezunları arasında belirgin farklılıklar olduğu” yönündeki hipotezimizi (hipotez-5) doğrulamaktadır.

10 Türk Dil Kurumu Güncel Türkçe Sözlüğü’ne (TDK) göre kuşak, “yaklaşık olarak aynı yıllarda doğmuş, aynı çağın şartlarını, dolayısıyla birbirine benzer sıkıntıları, kaderleri paylaşmış, benzer ödevlerle yükümlü olmuş kişiler topluluğu" (TDK, 2019) olarak tanımlanmaktadır. Genellikle Avrupa ülkeleri için yapılan ve sosyal araştırmalarda Türkiye için de kullanılan tasnife göre, yaklaşık olarak 1965-1979 yılları arasında doğanlar (X) Kuşağı, 1980 ve 1999 yılları arasında doğanlar (Y) Kuşağı, 2000 yılı sonrasında doğanlar (Z) Kuşağı olarak sınıflandırılmaktadır (Arslan ve Staub, 2015: 5). 
Tablo 7.

Siyasal Kimlik ile “IHH” Faktörü Arasındaki İlişki (Varyans Analizi)

\begin{tabular}{|l|l|l|l|l|l|}
\hline & $\begin{array}{l}\text { Kareler } \\
\text { Toplamı }\end{array}$ & Sd. & $\begin{array}{l}\text { Ortalamanın } \\
\text { Karesi }\end{array}$ & F & Sig. \\
\hline $\begin{array}{l}\text { Gruplar } \\
\text { Arasında }\end{array}$ & \multicolumn{1}{|l|}{1872,366} & 5 & 374,473 & 3,952 &, 002 \\
\hline $\begin{array}{l}\text { Gruplar } \\
\text { Dahilinde }\end{array}$ & 39603,094 & 418 & 94,744 & & \\
\hline Toplam & 41475,460 & 423 & & & \\
\hline \multicolumn{7}{|c|}{} & \\
\hline & N & Ort. & S.S. & $\begin{array}{l}\text { Çoklu Karşılaştırma } \\
\text { (Tamhane Testi) }\end{array}$ & \\
\hline Muhafazakâr & 158 & 51,1974 & 10,41133 & Milliyetçi* & \\
\hline Milliyetçi & 104 & 47,4098 & 8,70121 & Muhafazakâr* & \\
\hline İslamc1 & 92 & 50,6601 & 8,50168 & & \\
\hline Müslüman & 22 & 55,6788 & 12,18838 & & \\
\hline Demokrat & 28 & 50,7800 & 11,27080 & & \\
\hline Diğer & 20 & 46,9047 & 9,34668 & & \\
\hline Toplam & 424 & 50,1542 & 9,90206 & & \\
\hline
\end{tabular}

Not: (*) 0,05 düzeyinde anlamlı olduğunu göstermektedir.

Katılımcıların siyasal kimlikleri ile ilk faktör arasındaki ilişki de anlamlı bir ilişkidir $(\mathrm{F}=3,952, \mathrm{p}=, 002)($ Bkz. Tablo 7). Buna göre kendisini "Milliyetçi”" olarak tanımlayanlar ile kendisini "Muhafazakâr" olarak tanımlayanlar arasında anlamlı bir farklılık vardır (hipotez-7). Milliyetçilerin bu faktör altındaki ortalaması diğer siyasal kimliklere göre oldukça düşüktür. Bu veri dolayısıyla kendisini "Milliyetçi” olarak tanımlayan katılımcıların siyasal görüşlerinin İHL mezunu olmaktan fazla etkilenmediğini söylemek mümkündür. "Milliyetçiler" açısından siyasal görüşlerin şekillenmesinde ailenin daha etkili olduğu düşünülmektedir. Ailenin siyasal toplumsallaşma sürecindeki baskın etkisinin bu analiz dolayısıyla da ortaya çıktığı söylenebilir.

Tablo 4'te verilen ortalamalar göz önünde bulundurulduğunda İHL mezunlarının siyasal toplumsallaşma sürecine etki eden en önemli unsurlar "Devletin izlediği politikalar" (Ort: 2,93) ve "Siyasal olaylar ve güncel siyasal gelişmeler" (Ort: 2,90) olarak görünmektedir. Çalışmanın teorik kısmında tartışıldığı üzere, İHL'lerin tarihsel süreçte devlet eliyle doğrudan olumlu veya olumsuz bazı düzenlemelere muhatap olduğu bilinmektedir. Şüphesiz bu düzenlemeler İHL mezunlarını da etkilemiştir. Ancak İHL'ler haricinde, ülkenin genel siyaseti bakımından hükümetlerin diğer alanlarda uyguladığı politikaların ve güncel siyasal gelişmelerin katılımcıların siyasal toplumsallaşma sürecine olan etkisinin diğer aracılara ve unsurlara nispeten daha 
yüksek düzeyde olduğu görülmektedir. "Devletin izlediği politikalar" ve "güncel siyasal olaylar/gelişmeler" etkenlerine en yakın ortalamaya sahip aracı ise "medya" (Ort: 2,61) olmuştur. Katılımcıların siyasal olayları takip etmede tercih ettikleri basılı ve görsel medya organlarının İHL mezunlarının siyasal toplumsallaşma sürecindeki etkisi oldukça yüksektir. Medya, ölçek içerisinde en yüksek üçüncü ortalamaya sahiptir.

\section{Sonuç}

Araştırmadan elde edilen bulgulara göre, siyasal toplumsallaşma sürecinde İHL'lerin mezunları üzerinde aile ve siyasal olaylar gibi faktörlere göre sınırlı oranda bir etkisinin olduğu sonucuna ulaşılmıştır. İHL mezunlarının sahip oldukları siyasal görüşleri genel olarak ailelerinden tevarüs ettiklerini ve dolayısıyla mevcut siyasal görüşlerinin ana hatlarıyla İHL eğitimleri öncesinde de varolduğunu söylemek mümkündür. Bu bakımdan belirli siyasal kimliklere (Sağcı, Muhafazakâr, İslamcı, Milliyetçi vb.) sahip ebeveynlerin, ideolojik amaçlar gütmekten ziyade dini inanç veya hassasiyetlerinin yeni kuşaklara/nesillerine aktarılmasını sağlamak amacıyla çocuklarını bu okullara yönlendirdikleri söylenebilir. Çocuklarını İHL'lere gönderen ailelerin (veya toplumsal tabanın) temel amaçlarından birisi de dini eğitim talebiyle beraber evlatlarının çağın gerektirdiği bilimsel/teknik/modern bilgi kaynaklarına erişerek mezuniyetten sonra iş bulmayı kolaylaştıracak bir diplomaya sahip olmalarıdır. Bu diplomanın devlet dairelerine ve üniversitelere girişte geçerli olması da diğer önemli beklentidir. Aksi takdirde veliler ve öğrenciler başka bir okula yönelebilmektedir. Bunun en önemli kanıtı 28 Şubat sürecinde yaşanan katsayı uygulamasından sonra İHL'lerdeki öğrenci sayısında yaşanan belirgin düşüştür.

Araştırmanın sonuçlarına göre İHL'lerden son dönemlerde mezun olan gençlerin siyasal kimlik anlamında kendilerini "Muhafazakâr" veya "İslamcı" olmaktan daha çok "Milliyetçi" olarak tanımladıkları görülmüştür. Ayrıca, genç mezunlar "İmam Hatiplilik" kimliğine eski mezunlar kadar önem vermemekte ve siyasal görüşlerinin İHL'ler tarafından etkilendiğini düşünmemektedir. İHL mezunlarının siyasal ve toplumsal kimliklerine bir tehdit olarak görülen sorunların günümüzde çözüme kavuşmuş olması (katsayı engeli, askerlik ve polislik mesleklerine giriş yasağı, başörtüsü sorunları vb.) bu değişimin temel nedeni olarak düşünülebilir. $\mathrm{Bu}$ anlamda her ne kadar eski mezunlar tarafından ciddi manada eleştirilseler de genç mezunların sahip olduğu siyasal tutum ve eğilimlerdeki bu farklılıklar, İHL'ler ve siyaset ilişkisi bağlamında süregelen tartışmalar açısından sürecin normalleşmesi olarak görülebilir. Gelinen noktada, bu bulgular İHL'lerden genellikle siyasal İslamcı nesiller yetiştiği yönündeki iddiaları (zira araştırma sonuçları böyle bir iddiayı desteklemekten çok uzaktır) daha sağlıklı bir zemine taşıyabilecek niteliktedir. Başka bir ifadeyle araştırma sonucunda elde edilen bulgular, İHL'lerin Türkiye'de artık siyasal gündemin bir öznesi olmaktan daha çok bir eğitim kurumu olarak tartışılmasına ve bu okullarda verilen mesleki eğitimin niteliğine odaklanılmasına katkı sağlayacaktır. 


\section{Kaynakça}

Akın, M. H. (2011). Toplumsallaşma Sözlüğü, Konya: Çizgi Kitabevi.

Akşit, B. (1993). Türkiye'de İslami Eğitim; Osmanlı'nın Son Dönemlerinde Medrese Reformu ve Cumhuriyet’te İmam Hatip Okulları, Çağdaş Türkiye'de İslam-Din, Siyaset, Edebiyat ve Laik Devlet, (Ed: Richard Tapper), İstanbul: Sarmal Yayınevi.

Akşit, B. ve Coşkun, M. K. (2005). Türkiye'nin Modernleşmesi Bağlamında İmam-Hatip Okulları, Modern Türkiye'de Siyasi Düşünce-6, İslamcılık, (Der: Yasin Aktay), 2. Baskı, İletişim Yayınları: İstanbul.

Alagöz, M. (2003). "Eğitim Sistemi İçerisinde İmam-Hatip Liselerinin Yeri”, II. Din Şûrası Tebliğ ve Müzakereleri, Ankara: Diyanet İşleri Başkanlığı Yayınları, 572-579.

Alkan, T. (1979). Siyasal Toplumsallaşma- Siyasal Bilincin Gelişmesinde Ailenin, Okulun ve Toplumsal Sinıfların Etkisi, Ankara: Kültür Bakanlığı Yayınları.

Arslan, A. ve Staub, S. (2015). "Kuşak Teorisi ve İçgirişimcilik Üzerine Bir Araştırma”, $K A \ddot{U}$ - İIBF Dergisi, 6 (11), 1-24.

Aşlamac1, İ. (2014). Pakistan Medreselerine Bir Model Olarak Imam Hatip Okulları, İstanbul: Dem Yayınları.

Ayhan, H. (2014). Türkiye’de Din Eğitimi, 3. Bask1, İstanbul: Dem Yayınları.

Beşirli, H. (2005). "Politik Sosyalizasyon Araştırmaları ve Politik Sosyalizasyon Sürecinin Bir Unsuru Olarak Kışla”, Sosyoloji Konferansları Dergisi (Istanbul Journal of Sociological Studies), Say1: 31, 251-261.

Easton, D. (1957). "The Function of Formal Education in a Political System", The School Review, Vol. 65, No. 3, Symposium: Social Science and Education, 304-316.

Easton, D. (1968). “The Theoretical Relevance of Political Socialization”, Canadian Journal Of Political Science / Revue Canadienne De Science Politique, 1(2), 125-146.

Easton, D. and Hess, R. D. (1962). "The Child's Political Word”, Midwest Journal of Political Science, 6(3), 229-246.

Ergin, O. (1977). Türk Maarif Tarihi, Cilt 1-2-5, İstanbul: Eser Matbaas1.

Erkuş, A. (2013). Davranış Bilimleri İçin Bilimsel Araştırma Süreci, 4. Baskı, Ankara: Seçkin Yayınevi.

Gökaçt1, M. A. (2005). Türkiye’de Din Eğitimi ve İmam Hatipler, İstanbul: İletişim Yayınları.

Gündüz, T. (1998). "Türkiye'de Cumhuriyet Dönemi Din Eğitimi Kronolojisi (1923-1998)”, Uludă̆ Üniversitesi İlahiyat Fakültesi Dergisi, 7(7), 543-557.

Gürbüz, S. ve Şahin, F. (2016). Sosyal Bilimlerde Araştırma Yöntemleri, 3. Bask1, Ankara: Seçkin Yayınlar1.

Hyman, H. H. (1969). Political Soscialisation, Free Press, New York.

Jaschke, G. (1972). Yeni Türkiye'de İslamlık, Ankara: Bilgi Yayınevi.

Kara, İ. (2005). İmam-Hatip Liselerini Yeniden Tartışmak, İmam-Hatip Liselerinde Eğitim ve Öğretim, (yayına hazırlayan: Mahmut Zengin) . İstanbul: Değerler Eğitimi Merkezi Yayınları. 
Kara, İ. (2017). Cumhuriyet Türkiyesinde Bir Mesele Olarak İslam-2.Cilt, 2. Basım, İstanbul: Dergâh Yayınları.

Kara, İ. (2019). Cumhuriyet Türkiyesinde Bir Mesele Olarak İslam-1.Cilt, 9. Basım, İstanbul: Dergâh Yayınları.

Karaman, H. (2014). İmam-Hatiplilik Şuuru, 7. Basım, İstanbul: Ensar Neşriyat.

Koştaş, M. (1987). "Sosyalleşme (Socialisation)”, Ankara Üniversitesi Illahiyat Fakültesi Dergisi, 29(1), 329-334.

MEB-SGB, (2019). Millî Eğitim Bakanlığı Strateji Geliştirme Başkanlığ1, Millı̂ Eğitim İstatistikleri, Örgün Eğitim 2018-2019, (http://sgb.meb.gov.tr/www/icerik_goruntule.php?KNO=361 (19.11.2019)

Öcal, M. (1999). “Kuruluşundan Günümüze İmam-Hatip Liseleri”, Din Eğitimi Araştırmaları Dergisi, Say1: 6, 201-254.

Öcal, M. (2015). Dünden Bugüne İmam-Hatip Liseleri (1913-2013), 100. Yllında Imam-Hatip Liseleri Sempozyumu-Bildiriler, (Ed: Recep Kaymakcan, Nuri Tınaz, Z. Şeyma Altın, Mahmut Zengin, Ahmet Yasin Okudan, Hulusi Yiğit), Ankara: Dem Yayınları.

Öcal, M. (2017). Osmanlı'dan Günümüze Türkiye'de Din Eğitimi, İstanbul: Dergâh Yayınları.

Özensel, E. ve Aydemir, M. A. (2016). Türkiye'de İmam Hatipli Olmak-Temel Sorunlar, Beklentiler ve Değer Yapıları, Konya: Çizgi Kitabevi.

Reed, H. A. (1955). “Turkey's New İmam-Hatip Schools”, Die Welt Der İslams, New Series, Vol. 4, Issue 2/3, 150-163.

Subaşı, N. (2004), “İmam-Hatipliler Üzerine: Teolojik Birikimin Modern Kaynakları”, Değerler Eğitimi Dergisi, 2 (6), 115-132.

TDK, (2019). Türk Dil Kurumu Güncel Türkçe Sözlük, http://www.tdk.gov.tr/index. php?option=com_gts\&arama=gts\&guid=TDK.GTS.585797d7d75545.78376984, (19.12.2019).

Türkkahraman, M. (2000). Siyasal Sosyalleşme ve Siyasal Sembolizm, İstanbul: Birey Yayıncılık.

Ünsür, A. (2005). Kuruluşundan Günümüze İmam-Hatip Liseleri, İstanbul: Ensar Neşriyat.

Yıdırım, A. ve Şimşek, H. (2005). Sosyal Bilimlerde Nitel Araştırma Yöntemleri, 5. Baskı, Ankara: Seçkin Yayınları. 